\title{
Composition Analysis and Antioxidant Activities of the Essential Oil and the Hydrosol Extracted from Rosmarinus officinalis L. and Lavandula angustifolia Mill. Produced in Jeju
}

\author{
Deok Hyeon Jeon · Jeong Yong Moon · Ho Bong Hyun - Somi Kim Cho*
}

\section{제주산 로즈마리와 라벤더(Rosmarinus officinalis L., Lavandula angustifolia Mill.)로부터 추출한 essential oil과 hydrosol의 성분 분석 및 항산화 활성}

전덕현 · 문정용 · 현호봉 · 김소미*

Received: 6 April 2013 / Accepted: 30 April 2013 / Published Online: 30 September 2013

(C) The Korean Society for Applied Biological Chemistry 2013

\begin{abstract}
Constituents of the essential oil (EO)s and hydrosol of rosemary (Rosmarinus officinalis L.) and lavender (Lavandula angustifolia Mill.) were analyzed by gas chromatography-mass spectrometry (GC-MS). The identified major constituents were $\alpha$ pinene $(40.96 \%)$, camphor $(34.44 \%)$, verbenone $(45.31 \%)$, and camphor $(67.04 \%)$ in rosemary EO, lavender EO, rosemary hydrosol, and lavender hydrosol, respectively. The antioxidant activity of EO and hydrosol extracted from rosemary and lavender were evaluated. Both EO showed di(phenyl)-(2,4,6-trinitrophenyl) iminoazanium (DPPH) and 2,2'-azino-bis(3-ethylbenzthiazoline6-sulphonic acid) free radical scavenging activities as well as $\mathrm{Fe}^{2+}$ ion chelating activity but no alkyl radical scavenging activity. Rosemary EO showed higher DPPH radical scavenging activity than lavender, whereas lavender EO showed higher $\mathrm{Fe}^{2+}$ ion chelating activity. Both rosemary and lavender hydrosols showed alkyl radical scavenging activity, but only lavender hydrosol
\end{abstract}

D. H. Jeon · H. B. Hyun

Faculty of Biotechnology, College of Applied Life Sciences, Jeju National University, Jeju 690-756, Republic of Korea

J. Y. Moon · S. K. Cho

Subtropical Horticulture Research Institute, Jeju National University, Jeju 690-756, Republic of Korea

*Corresponding author (S. K. Cho: somikim@jejunu.ac.kr; phd.kim.somi@gmail.com) showed an activity on $\mathrm{Fe}^{2+}$ chelating assay. Both rosemary and lavender hydrosols also protected the dermal fibroblast and the $\mathrm{HaCaT}$ keratinocytes against $\mathrm{H}_{2} \mathrm{O}_{2}$-induced cytotoxicity.

Keywords antioxidant activity $\cdot$ essential Oil $\cdot$ hydrosol $\cdot$ lavender $\cdot$ rosemary

\section{서 론}

자유 라디칼의 과발현은 세포막의 지질 과산화와, 심혈관 질환, 돌연변이 유발, 당뇨병, 국소 빈혈, 빈혈성 재관류 손상, 관상 동맥 죽상 경화증, 알츠하이머, 그리고 암의 발생뿐만 아니라 노화 등 다양한 병리생리학적 장애를 일으킨다(Smith 등, 2002). 따라서 이러한 자유 라디칼에 의해 생성되는 활성산소종(reactive oxygen species, ROS)의 체내 축적을 예방하기 위한 천연자원 의 연구가 진행되고 있다(Rim 등, 2000; Lee 등, 2003). 산화 손상을 최소화 하기 위한 방법으로서 항산화 식품의 섭취를 증 가시키는 것은 중요하다. 따라서 항산화 식품에 대한 연구는 인 간의 질병 예방과 자유 라디칼에 의해 일어나는 질병 치료에 도움이 될 것이다(Kadri 등, 2011).

아로마 식물은 민속의학과 상업적 개발에 상당한 잠재력을 가지고 있으며, 이미 조미료나, 화장품, 의약품 등으로 사용되 고 있다(Boussaada 등, 2008). 그 중 로즈마리(Rosmarimus officinalis 
L.)는 Lamiaceae과에 속하며, 전세계에서 널리 재배되고 있다. 특히 지중해식에서 음식의 맛의 향상을 위한 향신료로 많이 이 용되며, 항산화 활성을 가지는 것으로 보고 되어 있다(Fernandez 등, 2005; Biljana 등, 2007; Adel 등, 2011). 또한, 라벤더 (Lavandula angustifolia Mill.)는 Lamiaceae 과의 식물로서, 25-30 종이 열대 아프리카와 아시아, 지중해 지역에 퍼져있으 며(Piccaglia 등, 1993), 강한 항산화 활동을 가진다고 알려져 있 다(Marulanda 등, 2007; $\mathrm{Lu}$ 등, 2010; Monica 등 2013). 이 러한 아로마 식물로부터 추출한 에센셜 오일의 대부분의 성분 은 테르펜, 세스퀴테르펜, 디페르펜, 트리테르펜과 페닐 프로페 노이드계 화합물들이다(Shin 등, 2012). 또한 아로마 에센셜 오 일은 강한 항균력도 가지고 있으며(Reichling 등, 2009), 피부를 통해 노폐물을 제거해주어 피부 노화방지 및 피부 재생의 효과 도 가지고 있다(Kim 등, 2011).

이처럼 허브 로즈마리와 라벤더의 항산화 효과에 대한 연구 는 이미 많은 진행이 되었으며, 이 두 가지 허브 에센셜 오일 의 항산화 효능을 비교한 연구 또한 진행되고 있으나(Alfreda and Takayuky, 2007; Shin 등, 2012), 에센셜 오일 추출과정 중 발생되는 부산물인 하이드로졸(hydrosol)에 대한 연구는 아 직 미흡하다. 따라서 본 연구에서는 제주산 로즈마리와 라벤더 로부터 추출한 에센설 오일과 추출과정 중 발생된 하이드로졸 에 대한 항산화 효능 탐색을 탐색하고, $\mathrm{GC} / \mathrm{MS}$ 를 통하여 성분 을 분석하였다.

\section{재료 및 방법}

재료. 제주도 서귀포 표선면에 위치한 (주)어반파머스 농장에서 재배 생산한 로즈마리(Rosmarinus officinalis)와 라벤더(Lavandula angustifolia)의 줄기와 잎을 2012년 여름에 채취하여 건조 후 사용하였다. 또한 모든 시약들은 Sigma Chemical (USA)와 Invitrogen Gibco (USA)에서 구입하여 사용하였다.

추출물 제조 방법. $100 \mathrm{~g}$ 의 시료를 Clevenger형 장치를 이용하 여 3 시간 동안 수증기 증류법으로 에센셜 오일과 하이드로졸로 분리 분획한 후 $-20^{\circ} \mathrm{C}$ 에 보관, 사용하였다. 회수된 에센셜 오 일의 수율은 로즈마리 에센셜 오일이 $2.15 \%$, 라벤더 에센셜 오 일은 $1.386 \%$ 의 수율을 나타냈으며, 이때 하이드로졸은 증류 추 출 시 건물 $\mathrm{g}$ 당 가해 준 증기의 양만큼 회수되었다.

기체 크로마토그래피-질량분석(GC-MS). 기체크로마토그래피 분 석은 Shimadzu GC-MS (Model QP-2010, Shimadzu Co., Japan) 을 사용하였다(electron impact, ionization voltage $70 \mathrm{eV}$ ). GC column ( $30 \mathrm{~m}$ length, $0.25 \mathrm{~mm}$ inner diameter, $0.25 \mu \mathrm{m}$ film thickness)으로는 Rtx-5MS를 사용하였다. 오븐온도는 $40^{\circ} \mathrm{C}$ 에서 2 분간 머문 후 $200^{\circ} \mathrm{C}$ 까지 $3^{\circ} \mathrm{C} / \mathrm{min}$ 속도로 승온한 다음 5 분간 머물고, 다시 $250^{\circ} \mathrm{C}$ 까지 $5^{\circ} \mathrm{C} / \mathrm{min}$ 속도로 승온하도록 설정하였 다. 각 화합물의 잠정적인 동정은 WILEY7과 NIST library data에 의해 결정하였다.

세포 독성 측정. 세포주는 피부세포주인 Fibroblast와 $\mathrm{HaCaT}$ 을 사용하였으며, 각각 $10 \%$ fetal bovine serum가 첨가된 Dulbecco's Modified Eagle Medium, RPMI1640 배지를 사용하였다. $37^{\circ} \mathrm{C}$, $5 \% \mathrm{CO}_{2}$ incubator에서 2-3일 간격으로 계대 배양 하면서 사용 하였다. $\mathrm{H}_{2} \mathrm{O}_{2}$ 에 의한 산화스트레스 억제효과는 MTT-assay를 이 용하여 측정하였으며, Hansen등(1989)의 방법을 변형하여 확인 하였다. 세포들은 각각 96 well plate에 well당 $1 \times 10^{5}$ cell $/ \mathrm{mL}$
의 양으로 $190 \mu \mathrm{L}$ 씩 분주하여, $37^{\circ} \mathrm{C}, 5 \% \mathrm{CO}_{2}$ incubator에서 16 시간 동안 전 배양 하였다. 추출물들을 각각 농도별로 $5 \mu \mathrm{L}$ 씩 처리하고 1시간 후 $\mathrm{H}_{2} \mathrm{O}_{2}$ 를 Fibroblast와 $\mathrm{HaCaT}$ 세포주에 농도별로 처리한 후 산화스트레스를 유발에 의한 세포의 생존 율을 측정하였다. Fibroblast와 $\mathrm{HaCaT}$ 세포의 생존율이 55-65\% 에 도달할 수 있는 $\mathrm{H}_{2} \mathrm{O}_{2}$ 의 농도를 결정하고 $140,180 \mu \mathrm{M}$ 농 도로 $5 \mu \mathrm{L}$ 씩 4 시간 동안 처리하였다. 배지를 걷어내고, MTT 시약 $(5 \mathrm{mg} / \mathrm{mL})$ 을 처리하여 4시간 후, 다시 배지를 걷어내고 $150 \mu \mathrm{L} \mathrm{DMSO}$ 에 녹여 $570 \mathrm{~nm}$ 에서 흡광도를 측정하였다. 흡광 도 측정 시 microplate reader (Tecan, Austria)를 사용하였다.

Radical 소거능 측정. di(phenyl)-(2,4,6-trinitrophenyl)iminoazanium (DPPH) 라디칼 소거능은 Cavin 등(1998)의 방법을 변형하여 측 정하였다. 에탄올에 용해시킨 $200 \mu \mathrm{M}$, DPPH $160 \mu \mathrm{L}$ 와 농도별 로 준비한 시료 $40 \mu \mathrm{L}$ 를 섞은 후 1 시간 동안 실온에서 교반 및 반응 시킨 후 $517 \mathrm{~nm}$ 에서 흡광도를 측정했으며 양성대조군으로 는 cathechin을 사용했다. Alkyl 라디칼 소거능은 Hiramoto 등 (1993)의 방법에 따라 측정하였다. $20 \mu \mathrm{L}$ 의 $\mathrm{PBS}, 40 \mathrm{mM}$ $\mathrm{AAPH}, 40 \mathrm{mM}$ 4-POBN과 농도별 시료를 차례로 첨가하여 $37^{\circ} \mathrm{C}$ 항온 수조에서 30 분간 반응시킨 다음 capillary tube로 옮 겨 ESR spectrometer로 측정하였다. 측정 조건은 central field $3475 \mathrm{G}$, modulation frequency $100 \mathrm{kHz}$, modulation amplitude $2 \mathrm{G}$, microwave power $10 \mathrm{~mW}$, gain $6.3 \times 10^{5}$, temperature 298 K였다. 2,2'-azino-bis(3-ethylbenzthiazoline-6-sulphonic acid) (ABTS) assay 방법은 기존에 보고된 방법을 변형하여 실시했으 며( $\operatorname{Re}$ 등, 1999), 양성대조군으로는 cathechin을 사용했다. ABTS 용액은 $7 \mathrm{mM} \mathrm{ABTS}$ 와 $2.45 \mathrm{mM} \mathrm{K} \mathrm{S}_{2} \mathrm{O}_{8}$ 를 섞어 16시 간 동안 $-4^{\circ} \mathrm{C}$ 암소에 보관하여 준비하였으며, optical density 값이 $0.700 \pm 0.005$ 에 도달하게 $\mathrm{PBS}(\mathrm{pH}$ 7.4)로 희석하였다. 큐벳 에 $\mathrm{ABTS}$ 용액과 시료를 각각 $100,900 \mu \mathrm{L}$ 씩 혼합하여 실온에 서 10 분간 반응시킨 후, $734 \mathrm{~nm}$ 에서 흡광도를 측정했으며 $\alpha$ tocopherol을 양성대조군으로 사용하였다. $\mathrm{Fe}^{2+}$ ion chelating activity의 측정은 Oyaizu (1986) 등의 방법을 변형하여 측정하 였다. 시료 $250 \mu \mathrm{L}$ 에 $2 \mathrm{mM} \mathrm{FeCl} 25 \mu \mathrm{L}$ 를 가한 후, $5 \mathrm{mM}$ ferrozine $10 \mu \mathrm{L}$ 를 넣어서 10 분 동안 실온에서 반응시켰다. 반 응물은 ESR spectrometer (Jeol Co. Ltd., Japan)를 이용하여 $562 \mathrm{~nm}$ 에서 흡광도를 측정했으며, 양성대조군으로는 Ethylenediaminetetraacetic acid를 사용했다. 라디칼 소거능은 아래와 같 은 공식에 대입하여 계산하였다.

\author{
라디칼 소거능(\%) \\ $=([$ control 흡광도 - sample 흡광도 $] /$ control 흡광도 $) \times 100 \%$
}

\section{결과 및 고찰}

Radical 소거능 활성. DPPH라디칼 소거능은 에센셜 오일의 경 우에만 활성을 나타내었으며 하이드로졸에서는 그 활성이 나타 나지 않았다. 로즈마리 에센셜 오일의 경우 실험에 적용한 모 든 농도에서 $(50,100,200,400 \mathrm{mg} / \mathrm{mL})$ 농도 의존적인 라디칼 소거능(27.33, 47.73, 72.80, 91.33\%)을 나타냈으며(Fig. 1A), 동일한 농도로 첨가한 라벤더 에센셜 오일의 라디칼 소거능 $(14.53,24.53,42.80,64.67 \%)$ 보다 높은 소거 활성을 나타내었 다(Fig. 1B). 한편 alkyl 라디칼 소거능의 경우에는, 에션설 오 일의 라디칼 소거 활성은 거의 관찰되지 않았으나 하이드로졸 

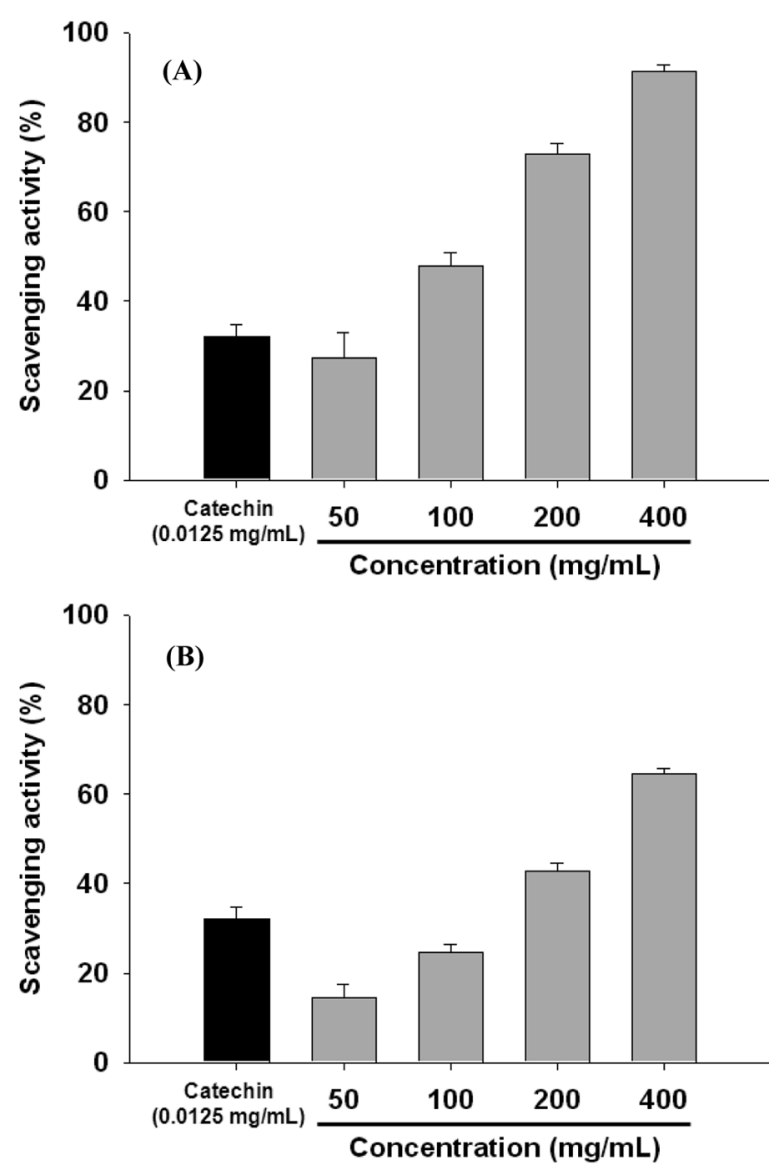

Fig. 1 DPPH radical scavenging activity of the herb essential oils. (A) Rosemary essential oil, (B) Lavender essential oil. Catechin $(12.5 \mu \mathrm{g})$ $\mathrm{mL}$ ) was used as positive control. The data were expressed as the SD \pm $(n=3)$.

에서 소거 활성이 나타남을 확인했다. 로즈마리 하이드로졸의 경 우 $100,200,400 \mathrm{mg} / \mathrm{mL}$ 농도에서 $49.82,64.74,83.00 \%$ 의 alkyl 라디칼 소거 활성을 나타내었으며(Fig. 2A), 같은 농도의 라벤더 하이드로졸에서는 $12.46,30.70,68.27 \%$ 의 라디칼 소거 능을 나타내었다(Fig. 2B). ABTS 라디칼에 대해서, 로즈마리 에 센셜 오일은 $5,10,20 \mathrm{mg} / \mathrm{mL}$ 농도에서 $5.92,18.92,22.71 \%$ 의 소거 활성을 나타냈으며(Fig. 3A), 라벤더 에센셜 오일도 로 즈마리 에센설 오일과 비슷한 활성을 나타냈다(Fig. $3 \mathrm{~B}$ ). $\mathrm{Fe}^{2+}$ ion 킬레이팅 활성의 경우, 에센셜 오일과 하이드로졸 모두 활 성을 나타냈다. 로즈마리 에센셜 오일은 $5,10,20,40 \mathrm{mg} / \mathrm{mL}$ 농도에서 각각 $7.89,30.47,43.70,75.97 \%$ 의 킬레이팅 효능을 나타낸 반면(Fig. 4A), 라벤더 에센셜 오일의 경우 더 낮은 농 도인 $0.3125,0.625,1.25,2.5 \mathrm{mg} / \mathrm{mL}$ 농도에서 각각 26.94 , $47.71,83.52 \%$ 의 활성을 나타냈다(Fig. 4B). 한편, 로즈마리 하 이드로졸은 $\mathrm{Fe}^{2+}$ ion 킬레이팅 효능을 활성이 측정되지 않았으 나, 라벤더 하이드로졸은 $125,250,500,1,000 \mathrm{mg} / \mathrm{mL}$ 농도에 서 $0.20,1.57,30.84,59.81 \%$ 의 활성을 나타냈다(Fig. 4C). Woo 등은(2010a) 국내외에서 수집한 로즈마리 에센셜 오일 31 점의 항산화 활성을 측정한 결과, 시료별로 $4.8-96.0 \%$ 의 현저 한 차이를 나타낸다고 보고한 바 있다. 이번 연구에 사용된 로 즈마리 에센셜 오일의 DPPH 라디칼 소거활성과 Woo 등
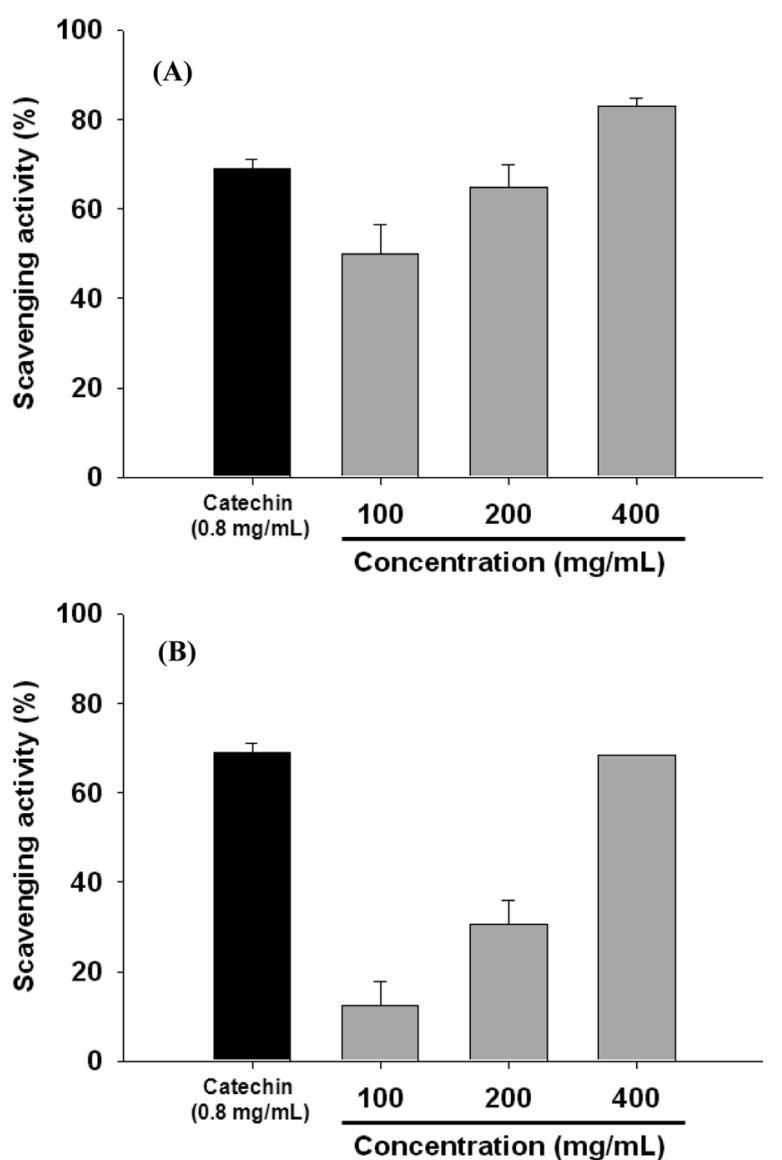

Fig. 2 Alkyl radical scavenging activity of the herb hydrosols. (A) Rosemary hydrosol, (B) Lavender hydrosol. Catechin $(12.5 \mu \mathrm{g} / \mathrm{mL})$ was used as positive control. The data were expressed as the $\mathrm{SD} \pm(n=3)$.

(2010a)이 보고했던 생산국 별 로즈마리 에센셜 오일의 활성을 비교한 결과, 동일한 양 $(2 \mathrm{~g})$ 의 시료에 대해 약 $6.83 \%$ 의 $\mathrm{DPPH}$ 라디칼 소거능을 나타내어 $5.99 \%$ 의 활성을 나타낸 프랑스산 로 즈마리 에센셜 오일과 $7.96 \%$ 의 활성을 보인 튀니지 산과 항산 화 활성이 유사한 것으로 확인되었다. 또한 본 연구에 사용한 라벤더 에센셜 오일의 DPPH 소거능을 Woo 등(2010b)이 보고 한 32점의 라벤더 에센셜 오일의 활성과 비교한 결과, 오스트 레일리아 산의 $3.26 \%$ 와 비슷한 활성을 보였다. 에센셜 오일과 는 대조적으로 하이드로졸의 항산화 효능에 대한 보고는 검색 이 되지 않아 비교를 할 수 없었으나, 에센셜 오일에서는 확인 되지 않았던 alkyl 라디칼 소거능이 로즈마리, 라벤더 하이드로 졸 시료에서 확인되었으며, 두 에센셜 오일과 더불어 라벤더 하 이드로졸에 의한 $\mathrm{Fe}^{2+}$ ion 킬레이팅 활성도 확인되었다.

피부 세포주에서의 항산화 활성. 피부 세포주인 fibroblast와 $\mathrm{HaCaT}$ 세포에 에센셜 오일과, 하이드로졸을 전처리 한 후 $\mathrm{H}_{2} \mathrm{O}_{2}$ 를 처리하여 산화스트레스를 유발시키고 이를 억제하는 효능을 확인하였다. Fibroblast에서 로즈마리와 라벤더 에센셜 오일(62.5 $\mu \mathrm{g} / \mathrm{mL}$ )을 전 처리함으로써 산화스트레스로 인하여 $63.80 \%$ 로 감 소한 세포 생존율을 각각 $70.05 \%, 74.90 \%$ 로 회복시켰으며, 하 이드로졸 $(5 \mathrm{mg} / \mathrm{mL})$ 을 전 처리한 경우에는 $81.17 \%$ 와 $89.01 \%$ 까 지 세포생존율이 증가하였다(Fig. $5 \mathrm{~A}$ ). 또한 $\mathrm{HaCaT}$ 에서는 산화 

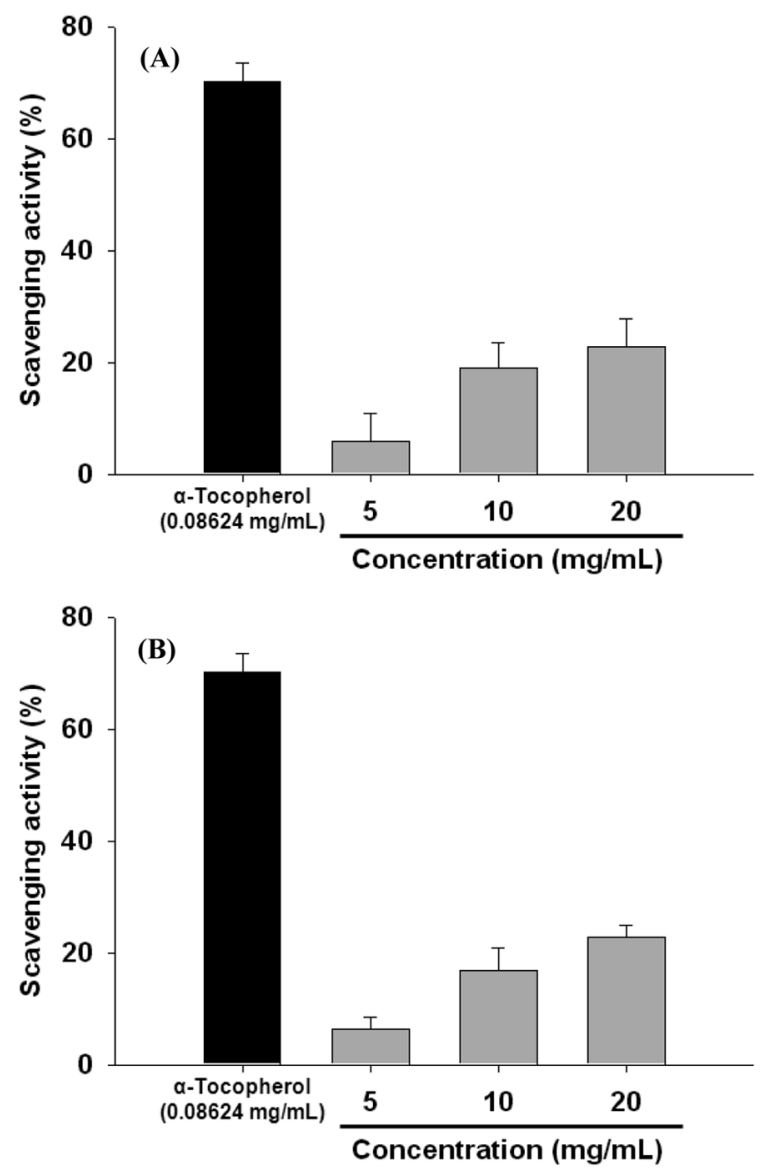

Fig. 3 ABTS radical scavenging activity of the essential oils. (A) Rosemary essential oil, (B) Lavender essential oil. $\alpha$-Tocopherol $(200 \mu \mathrm{M})$ was used as positive control. The data were expressed as the $\mathrm{SD} \pm(n=3)$.

스트레스로 $53.82 \%$ 까지 감소하였던 세포 생존율이 로즈마리와 라벤더 에센셜 오일 $(62.5 \mu \mathrm{g} / \mathrm{mL})$ 전처리에 의해 각각 $63.36 \%$, $58.89 \%$ 로 회복하였고, 로즈마리, 라벤더 하이드로졸 전처리에 의해서는 각각 $70.29 \%, 66.43 \%$ 로 회복시키는 것을 확인할 수 있었다(Fig. 5B). 특히, 라벤더 하이드로졸을 fibroblast 세포에 $5 \mathrm{mg} / \mathrm{mL}$ 처리하였을 때의 세포생존율은 표준항산화제인 $\alpha$ tocopherol을 $200 \mu \mathrm{M}$ 처리하였을 때보다 더 높게 나타냈다. Yang 등은(2010) 라벤더 에센셜 오일이 피부암, 빛에 의한 피 부손상 및 노화를 억제한다고 보고 하였으며, Calabrese 등은 (2001) 로즈마리 에센셜 오일이 자유 라디칼에 의한 피부손상 을 최소화 할 수 있다 보고하였다. 따라서 본 연구 결과에서 나 타난 로즈마리, 라벤더 에센셜 오일의 항산화 효능은 다른 연 구자들이 보고한 결과들과 유사했으며, 하이드로졸의 산화스트 레스에 대한 세포독성 억제능은 처음으로 확인되었다.

성분 분석. 기체 크로마토그래피-질량분석(GC-MS)를 이용하여 제주산 로즈마리, 라벤더 에센셜 오일과 하이드로졸 성분을 분 석한 결과는 Table 1과 같다. 제주산 로즈마리 에센셜 오일에 서는 $\alpha$-pinene $(40.96 \%)$ 이 가장 높은 함량을 나타냈으며, Biljana 등(2007)이 보고한 세르비아산(13.5\%)과 Adel 등(2011) 이 보고한 튀니지산 $(7.90 \%)$ 보다 $\alpha$-pinene 함량이 높았다. 1,8cineole의 함량은 $21.3 \%$ 로 세르비아산 $(2.1 \%)$ 보다 높았으며 튀
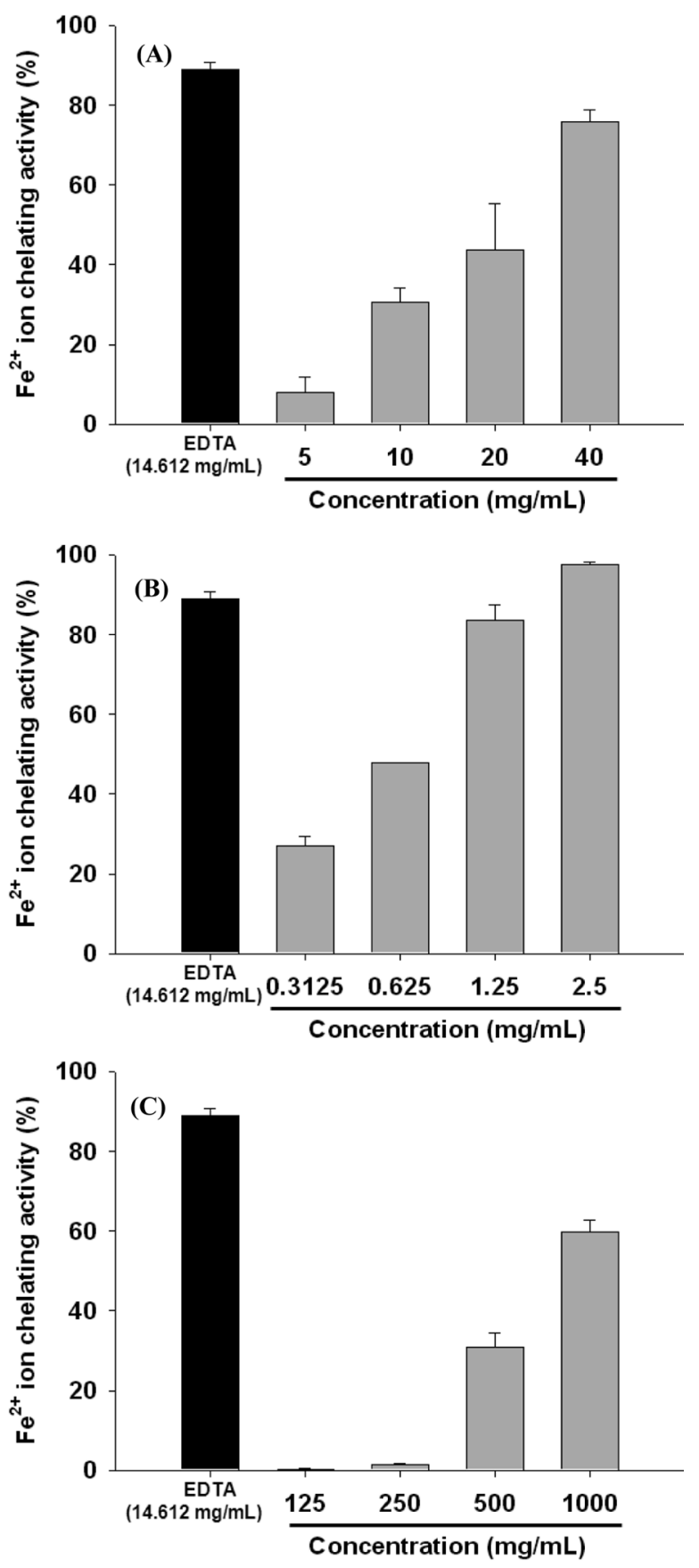

Fig. $4 \mathrm{Fe}^{2+}$ ion chelating activity of the essential oils and the hydrosols. (A) Rosemary essential oil, (B) Lavender essential oil, (C) Lavender hydrosol. EDTA $(50 \mu \mathrm{M})$ was used as positive control. The data were expressed as the $\mathrm{SD} \pm(n=3)$.

니지산(35.32\%)보다는 낮게 나타났다. 그 다음으로는 camphene (5.4\%), 2- $\beta$-pinene (4.49\%), L-limonene (4.05\%), endo-borneol (2.37\%), trans-caryophyllene (2.04\%), $\beta$-myrcene $(1.97 \%)$, linalool $(1.49 \%)$, camphor $(1.46 \%)$ 등의 순으로 함유되어 있었다. 또한. 제주산 라벤더 에센셜 오일에서는 오스트레일리아 산이나 프랑 스산에 $40.93 \%, 44.24 \%$ 로 과량 존재하는 linalyl acetate가 존 재하지 않았으며(Woo 등, 2010), 제주산 로즈마리 에센셜 오일 

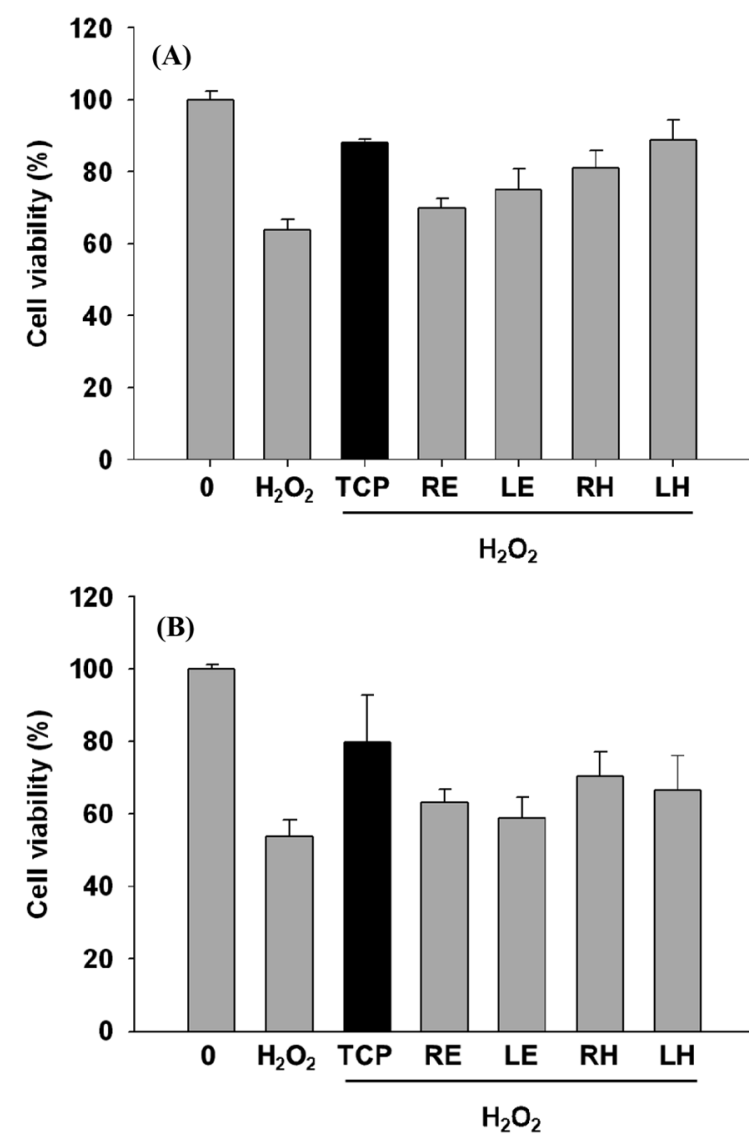

Fig. 5 Protective effects of essential oils and hydrosols on $\mathrm{H}_{2} \mathrm{O}_{2}$-induced cytotoxicity. (A) Dermal fibroblast cells were treated for $1 \mathrm{~h}$ with indicated samples and then incubated with $140 \mu \mathrm{M}$ of $\mathrm{H}_{2} \mathrm{O}_{2}$ for $4 \mathrm{~h}$, (B) $\mathrm{HaCaT}$ cells were treated for $1 \mathrm{~h}$ with indicated samples and then incubated with $180 \mu \mathrm{M}$ of $\mathrm{H}_{2} \mathrm{O}_{2}$ for $4 \mathrm{~h}$. RE: Rosemary essential oil (62.5 $\mu \mathrm{g} / \mathrm{mL})$, LE: Lavender essential oil $(62.5 \mu \mathrm{g} / \mathrm{mL})$, RH: Rosemary hydrosol $(5 \mathrm{mg} / \mathrm{mL})$, LH: Lavender hydrosol $(5 \mathrm{mg} / \mathrm{mL})$. TCP: $\alpha$ Tocopherol $(200 \mu \mathrm{M})$ was used as positive control. The data were expressed as the $\mathrm{SD} \pm(n=3)$.

에서 미량으로 존재 하던 camphor가 $34.44 \%$ 로 가장 높게 나타 났다. 그 다음으로는 1,8 -cineole $(21.31 \%), \alpha$-fenchone $(13.22 \%)$, linalool (3.78\%), $\alpha$-pinene (3.73\%), eremophilene (3.59\%), L-limonene $(3.3 \%)$ camphene (3.22\%), 2- $\beta$-pinene $(1.58 \%)$ 등 의 순으로 함유되어 있었다. 제주산 로즈마리 하이드로졸에는 verbenone $(45.31 \%), \quad 1,8$-cineole $(28.57 \%)$, endo-borneol (8.77\%), camphor (5.57\%), 3-cyclohexene-1-methanol (4.95\%), 4-terpineol $(3.46 \%)$, linallool $(3.37 \%)$ 등이 함유되어 있었다. 제주산 라벤더 하이드로졸에서는 camphor가 $67.04 \%$ 로 함유량 이 가장 높게 나타났으며, bicyclo[2.2.1]heptan-2-one (16.16\%), 1,8-cineole (13.48\%), linalool (3.31\%) 등이 높은 함량을 나타 냈다. 제주산 에센셜 오일과 하이드로졸 모두에 다량 존재하는 linalool과 1,8-cineole은 $\mathrm{H}_{2} \mathrm{O}_{2}$ 에 의한 산화스트레스를 억제한다 는 보고가 있었으며, 로즈마리 에센셜 오일의 $\beta$-myrcene은 쥐 간세포에서 산화스트레스를 억제하며, $\gamma$-terpinene, terpinolene, geraniol은 높은 라디칼 소거 활성을 나타낸다는 보고가 있었다 (Ruberto and Baratta, 2000; Sait and Ahmet, 2000; Osman
Table 1 Composition of essential oils and hydrosols from Jeju rosemary (Rosmarinus officinalis L) and lavender (Lavandula angustifolia Mill.)

\begin{tabular}{|c|c|c|c|c|c|}
\hline \multirow{2}{*}{ Name } & \multirow{2}{*}{$\mathrm{RT}^{1)}$} & \multicolumn{4}{|c|}{ Area $\%{ }^{2)}$} \\
\hline & & $\mathrm{RE}^{3)}$ & $\mathrm{LE}^{4)}$ & $\mathrm{RH}^{5)}$ & $\mathrm{LH}^{6}$ \\
\hline Tricyclene & 10.268 & 0.23 & & & \\
\hline$\alpha$-Thujene & 10.544 & 0.37 & & & \\
\hline$\alpha$-Pinene & 10.853 & 40.96 & 3.73 & & \\
\hline Camphene & 11.488 & 5.4 & 3.22 & & \\
\hline Butylbenzene & 11.78 & 0.87 & & & \\
\hline$\beta$-Phellandrene & 12.71 & & 0.51 & & \\
\hline Sabinene & 12.727 & 0.15 & & & \\
\hline 2- $\beta$-Pinene & 12.837 & 4.49 & 1.58 & & \\
\hline$\beta$-Myrcene & 13.642 & 1.97 & 0.68 & & \\
\hline L-Phellandrene & 14.226 & 0.34 & & & \\
\hline$\alpha$-Terpinene & 14.84 & 0.79 & & & \\
\hline p-Cymene & 15.247 & 1.05 & 0.46 & & \\
\hline L-Limonene & 15.452 & 4.05 & 3.3 & & \\
\hline 1,8-Cineole & 15.564 & 21.3 & 21.31 & 28.57 & 13.49 \\
\hline$\gamma$-Terpinene & 16.991 & 1.4 & & & \\
\hline trans Sabinene hydrate & 17.412 & 0.14 & & & \\
\hline$\alpha$-Terpinolene & 18.489 & 0.93 & & & \\
\hline$(+)$-Fenchone & 18.734 & & 13.22 & & \\
\hline trans Sabinene hydrate & 19 & 0.05 & & & \\
\hline Linalool & 19.106 & 1.49 & 3.78 & 3.37 & 3.31 \\
\hline Filifolone & 19.289 & 0.16 & & & \\
\hline Bicyclo[2.2.1]heptan-2-one & 20.108 & & & & 16.16 \\
\hline chrysanthenone & 20.359 & 1.04 & & & \\
\hline Verbenol & 21.177 & 0.1 & & & \\
\hline Camphor & 21.302 & 1.46 & 34.44 & 5.57 & 67.04 \\
\hline Pinocamphone & 22.14 & 0.06 & & & \\
\hline Pinocarvone & 22.258 & 0.15 & & & \\
\hline (-)-Borneol & 22.405 & 2.37 & & 8.77 & \\
\hline L- $\alpha$-Terpineol & 22.584 & & 0.77 & & \\
\hline Iso-pinocamphone & 22.824 & 0.42 & & & \\
\hline 4-Terpineol & 22.976 & 0.59 & 1.03 & 3.46 & \\
\hline Cuminol & 23.525 & & 0.61 & & \\
\hline D- $\alpha$-Terpineol & 23.655 & 0.75 & 1.05 & & \\
\hline Myrtenol & 23.966 & 0.13 & 0.65 & & \\
\hline (cyclohex-3-enyl)methanol & 24.294 & & & 4.95 & \\
\hline Bicyclo[3.1.1]heptane & 24.303 & 0.19 & & & \\
\hline Verbenone & 24.572 & 1.27 & & 45.31 & \\
\hline$\beta$-Citronellol & 25.537 & 0.11 & & & \\
\hline trans-Geraniol & 26.799 & 1.22 & & & \\
\hline Citral & 27.581 & 0.09 & & & \\
\hline (-)-bornyl acetate & 28.291 & 1.28 & & & \\
\hline$\alpha$-Fenchyl acetate & 28.298 & & 0.92 & & \\
\hline Myrteyl acetate & 30.163 & & 0.84 & & \\
\hline Geranyl acetate & 32.773 & 0.18 & & & \\
\hline trans-Caryophyllene & 34.398 & 2.04 & & & \\
\hline$\alpha$-Humulene & 35.882 & 0.26 & & & \\
\hline Eremophilene & 37.441 & & 3.59 & & \\
\hline ar-Curcumene & 38.02 & & 0.37 & & \\
\hline$\delta$-Cadinene & 38.868 & & 0.94 & & \\
\hline cis- $\alpha$-Copaene- 8 -ol & 40.511 & & 0.52 & & \\
\hline (-)-Caryophyllene oxide & 41.347 & 0.15 & & & \\
\hline Veridiflorol & 41.736 & & 0.55 & & \\
\hline$\gamma$-1-cadinene aldehyde & 51.2 & & 0.91 & & \\
\hline N.I $I^{7)}$ & 55.593 & & 1.02 & & \\
\hline
\end{tabular}

${ }^{11}$ Retention time, ${ }^{2}$ Relative peak area percentage (peak area relative to the total peak area \%), ${ }^{3)}$ Rosemary essential oil, ${ }^{4}$ Lavender essential oil, ${ }^{5}$ Rosemary hydrosol, ${ }^{6}$ Lavender hydrosol, ${ }^{7)}$ Not identified 
등, 2011). 따라서 제주산 로즈마리, 라벤더 에센셜 오일과 하 이드로졸이 지닌 차별적인 항산화 효능은 이들 각 추출물에 공 통으로 함유되어 있는 항산화 성분들과 각 에센셜 오일과 하이 드로졸에 함유되어 있는 고유한 성분들의 종합적인 상호작용에 기인한 것으로 사료된다.

\section{초 록}

제주도에서 생산된 로즈마리(Rosmarinus officinalis L.)와 라벤 더(Lavandula angustifolia Mill.) 두 종의 허브 에센셜 오일과 하이드로졸 성분을 $\mathrm{GC}-\mathrm{MS}$ 로 분석하였다. 로즈마리 에센셜 오 일에는 $\alpha$-pinene $(40.96 \%)$ 의 함량이 가장 높았으며, 라벤더 에 센셜 오일에는 camphor $(34.44 \%)$ 가 가장 높았다. 로즈마리 하 이드로졸에는 verbenone이 $(45.31 \%)$ 가장 높게 나타났으며, 라 벤더 하이드로졸에서는 camphor $(67.04 \%)$ 로 가장 높게 나타났 다. 또한 로즈마리와 라벤더 에센셜 오일과 하이드로졸의 항산 화 효능을 검증해 본 결과, 두 종류의 에센셜 오일 모두 $\mathrm{DPPH}, \mathrm{ABTS}$ 라디칼 소거능과, $\mathrm{Fe}^{2+}$ ion 킬레이팅 활성을 나 타냈으나, alkyl 소거능은 거의 나타나지 않았다. DPPH 라디칼 소거능은 로즈마리 에센셜 오일이 라벤더 에센셜 오일보다 우 수한 반면, $\mathrm{Fe}^{2+}$ ion 킬레이팅 실험에서는 라벤더 에센셜 오일 이 로즈마리 에센셜 오일보다 더 우수했다. 로즈마리, 라벤더 하이드로졸 모두 alkyl 라디칼 소거능을 나타냈으나, 라벤더 하 이드로졸만이 $\mathrm{Fe}^{2+}$ ion 소거능을 나타냈다. 특히 $\mathrm{H}_{2} \mathrm{O}_{2}$ 에 의해 유도된 Fibroblast와 $\mathrm{HaCaT}$ 에서의 세포독성 실험에서 하이드로 졸이 에센셜 오일보다 우수한 세포사멸 억제능을 나타냈다.

Keywords 라벤더 · 로즈마리 · 에센셜 오일 · 하이드로졸 · 항산화 효능

감사의 글 본 연구는 지식경제부, 한국산업기술진흥원, 제주광역경제권 선 도산업지원단의 지원으로 수행된 광역경제권 선도산업 육성사업의 연구결과 입니다.

\section{References}

Adel K, Zied Z, Ines BC, Ahmed B, Néji G, Mohamed D et al. (2011) Chemical constituents and antioxidant properties of Rosmarinus officinalis L. essential oil cultivated from the South-Western of Tunisia. $J$ Med Plants Res 5, 5999-6004.

Alfreda W and Takayuky S (2007) Antioxidant Activities and Volatile Constituents of Various Essential Oils. J Agric Food Chem 55, 1737-42.

Biljana B, Neda MD, Isidora S, and Emilija J (2007) Antimicrobial and Antioxidant Properties of Rosemary and Sage (Rosmarinus officinalis L. and Salvia officinalis L., Lamiaceae) Essential Oils. J Agric Food Chem 55, 7879-85.

Boussaada O, Ammar S, Saidana D, Chriaa J, Chraif I, Daami M et al. (2008) Chemical composition and antimicrobial activity of volatile components from capitula and aerial parts of volatile components from capitula and aerial parts of Rhaponticum acaule DC growing wild in Tunisia. Microbiol Res 163, 87-95.

Calabrese V, Scapagnini G, Catalano C, Bates TE, Dinotta F, Micali G at al. (2001) Induction of heat shock protein synthesis in human skin fibroblasts in response to oxidative stress: regulation by a natural antioxidant from rosemary extract. Int J Tissue React 23, 51-8.

Cavin A, Hostettmann K, Dyatmyko W, and Potterat O (1998) Antioxidan and lipophilic constituents of Tinospora crispa. Planta Med 64, 393-6.
Fernandez LJ, Zhi N, Aleson CL, Perez AJA, and Kur V (2005) Antioxidant and antibacterial activities of natural extracts, application in beef meat balls. Meat Sci 69, 371-80.

Hiramoto K, Johkoh H, Sako K, and Kikugawa K (1993) DNA breaking activity of the carbon-centered radical generated from 2,2-azobis (2amidinopropane) hydrochloride (AAPH). Free Radical Res Commun 19, 323-32.

Kadri A, Zarai Z, Chobba IB, Békir A, Gharsallah N, Damak M et al. (2011) Chemical constituents and antioxidant properties of Rosmarinus officinalis L. essential oil cultivated from the South-Western of Tunisia. $J$ Med Plants Res 5, 6502-8.

Kim JH, Kim MJ, Choi SK, Bae SH, An SK, and Yoon YM (2011) Antioxidant and Antimicrobial Effects of Lemon and Eucalyptus Essential Oils. J Soc Cosmet Scientists Korea 37, 303-8

Lee SE, Hwang HJ, Ha JS, Jeong HS, and Kim JH (2003) Screening of medicinal plant extracts for antioxidant activity. Life Sci 73, 167-79.

Lu H, Li H, Lu H, Li XL, and Zhou AG (2010) Chemical composition of lavender essential oil and its antioxidant activity and inhibition against rhinitisrelated bacteria. Afr J Microbiol Res 4, 309-13.

Marulanda A, Porcel R, Barea JM, and Azcón R (2007) Drought tolerance and antioxidant activities in lavender plants colonized by native droughttolerant or drought-sensitive Glomus Species. Microbial Ecol 54, 54352.

Monica H, Oana C, Marius M, and Lucian H (2013) Neuroprotective effects of inhaled lavender oil on scopolamine-induced dementia via antioxidative activities in rats. Phytomedicine 20, 446-52.

Osman C, Llknur O, Sadettin T, Sedat Y, and Hakan O (2011) Antioxidative effects of curcumin, $\beta$-myrcene and 1,8-cineole against 2,3,7,8tetrachlorodibenzo- $p$-dioxin-induced oxidative stress in rats liver. Toxicol Ind Health 27, 447-53.

Oyaizu M (1986) Studies of products of browning reaction: antioxidative activities of products of browning reaction prepared from glucosamine. Jpn J Nutr 44, 307-15.

Piccaglia R, Marotti M, Giovanelli E, Deans SG, and Eaglesham E (1993) Antibacterial and antioxidant properties of Mediterranean aromatic plants. Ind Crop Prod 2, 47-50.

Re R, Pellegrini N, Proteggente A, Pannala A, Yang M, and Rice-Evans C (1999) Antioxidant activity applying an improved ABTS radical cation decolorization assay. Free Radic Biol Med 26, 1231-7.

Reichling J, Schnitzler P, Suschke U, and Saller R (2009) Essential oils of aromatic plants with antibacterial, antifungal, antiviral, and cytotoxic properties-an Overview. Forsch Komplementmed 16, 79.

Rim YS, Park YM, Park MS, Kim KY, Kim MJ, and Choi YH (2000) Screening of antioxidants and antimicrobial activity in native plants. Korean J Med Crop Sci 8, 324-50.

Ruberto G and Baratta MT (2000) Antioxidant activity of selected essential oil components in two model systems. Food Chem 69, 167-74.

Sait C and Ahmet O (2002) Effects of Intraperitoneally Administered Lipoic Acid, Vitamin E, and Linalool on the Level of Total Lipid and Fatty Acids in Guinea Pig Brain with Oxidative Stress Induced by $\mathrm{H}_{2} \mathrm{O}_{2} . J$ Biochem Mol Biol 35, 547-52.

Shin YH, Kim HJ, Lee JY, Cho YJ, and An BJ (2012) Major Compound Analysis and Assessment of Natural Essential Oil on Anti-Oxidative and Anti-Microbial Effects. J Life Sci 20, 1344-51.

Smith MA, Perry G, and Pryor WA (2002) Causes and consequences of oxidative stress in Alzheimer's disease $(1,2)$. Free Radical Biol Med 32, 1049.

Woo JH, Mok MG, Han KW, Lee SY, and Park KW (2010a) Aroma components and Antioxidant Activities of Pure Rosemary Essential Oil Goods Produced in Different Countries. Kor J Hort Sci Technol 28, 696700.

Woo JH, Mok MG, and Park KW (2010b) Aroma Component and Antioxidant Activities of Pure Lavender Essential Oil Goods in Different Produced Countries. Kor J Hort Sci Technol 28, 138-43.

Yang SA, Jeon SK, Lee EJ, Shim CH, and Lee IS (2010) Comparative study of the chemical composition and antioxidant activity of six essential oils and their components. Nat Pro Lett 24, 140-51. 